\title{
Sacralisation of the social space: A study of the trans-border expansion of the redemption camp of the Redeemed Christian Church of God
}

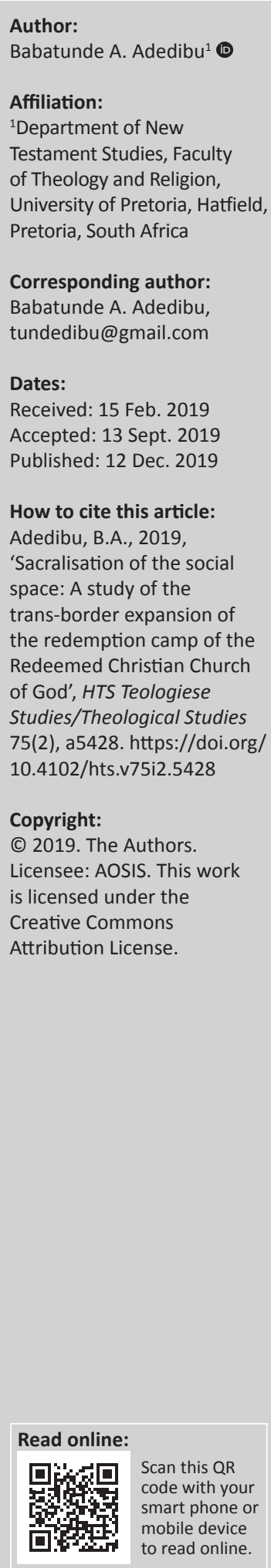

Urban cities in the sub-Saharan Africa have witnessed unprecedented transformation because of the proliferation of religious orders within the social landscape. From Nigeria, Ghana and Cameroon to Uganda, religious practitioners are actively involved in the spatial transformation through the construction of sacred spaces or prayer camps. The Redeemed Christian Church of God (RCCG) typifies one of the several examples of African Pentecostal denominations with transnational status in 200 countries across the world with the hub of its international office situated at the Redemption Camp, Mowe, Nigeria. The sacralisation of forest areas spanning 1600 ha of land has redefined religious institutions such as RCCG as perhaps one of the largest owners of private estate in Nigeria. However, there seems to be an intentional replication of the Redemption Camp, Mowe across Nigeria as well as across the Atlantic as part of the RCCG missionary enterprise. This study aims to utilise the ethnography of the Redemption Camps in Nigeria and Floyd, Texas, United States. The theoretical framework of social worlds is employed to examine the dynamics of religious creativity, innovations, contextual challenges of place-making involved in creating Redemption Camps across borders by the leadership of RCCG through the appropriation of religious capital of its community of sentiments.

Keywords: Redeemed Christian Church of God; Redemption Camp; Sacralisation; Placemaking; Nigeria; United States.

\section{Introduction}

The urban cities in Africa and in Diaspora have witnessed remarkable presence of religious orders as they emplaced themselves in the social and economic dynamics through sacralisation of economic and social landscape of these cities. Various views have been expressed by scholars in relation to place-making and the sacred that is reflective in the phenomenological approaches that are interdisciplinary in nature, especially between the disciplines of geography and religion. Significantly, and overtime, some have reflected on poetics of space in relation to the sacred as far back as the 20th century (Lefebvre 1991:120-121). Other geographers that contributed to the paradigm shift from the Cartesian concept of space to social and physical space embodying spatial exercise and the intricacy of power dynamics in the production of space included Soja (1989, 1996), Harvey (1993), Massey (1994) and a host of others. Knott (2010:30) noted that there were few exceptions to researchers interested in interdisciplinary or multidisciplinary research on space and environment.

Knott (2010:29-43) in his literature review on the previous scholarship on the discourse concerning the disciplinary boundaries amongst geographers and scholars of religion working on space and environment identified the contributions of Kong $(1990,2001)$ as pivotal. The broad mindedness of Kong $(1990,2001)$ is reflective of her initiative to call for a new understanding and pragmatic engagement with issues of space and religion. Kong $(1990,2001)$ was quick to notice the upsurge in the interest of geographers in the emerging interdisciplinary research on religion. However, Knott (2010), quoting Kong (1990, 2001), noted the intersection between the geography and religious space in the following submission:

I will also argue that religion deserves to be acknowledged fully in like manner alongside, race, class and gender in geographical analysis. Most significantly, I underline the geographic significance of examining religion, not least in the intersection of sacred and secular forces in the making of place. This is especially so in urban contexts where the sacred and secular and indeed, varieties of the sacred, frequently exist cheek by jowl. (p. 30) 
Kong's (2001:211-233) effort is reflected in her extensive literature review in the 1900s which Knott (2010:30) observed gave her insight into broad classification of these researches into 'religion, place and space focuses on power contestation, identity and discourse from those working in phenomenological tradition with regard to place and sacred'. It is pertinent to note that space and place are used interchangeably as places are parts of locations within space, which is corroborated by Knott (2005:29-31). From the forgoing, sociologists and geographers have been noted to be major contributors to the discourse on space and place-making with particular emphasis on economic and social development but with increasing attention on cultural exchange and movement.

Moreover, the forces of globalisation, migration, travels and mobility have the potential to create 'global places'. Massey (2005:268-281) argues that the place is redefined not as a result of its context but of other spaces and experiences. Consequentially, places are the product of contestation, and thus require negotiation. She asserted in her case study on the political negotiations of London, accentuating the resentments voiced between supporters of reasonably priced housing (and better wages) and those who celebrate (and wish to continue) are important with respect to space, which is important in the understanding of the politics of religious emplacement by religious groups. Massey (2005:181) highlights this comment from Deutsche that 'Conflict is not something that befalls an originally, or potentially, harmonious urban space. Urban space is the product of conflict'. The implosion of sacralisation of public places is not a new phenomenon in most cities across the globe. In fact, the ongoing de-sacralisation of religious spaces in the West to economic and social spaces might be on account of the effect of secularisation, but also it attests to the fact that religious spaces have always been part of spatial space in various communities. Eade (2011:157) alludes with respect to the British context as he posits that the appearance of 'purpose built mosques, madrasahs, temples and gurdwaras from the 1970s has followed a well-trodden path'.

Owing to the social, cultural and economic discontinuities experienced by migrants who are mostly members of the Redeemed Christian Church of God (RCCG) in Diaspora, the church leadership enters this sensuous and spatial politics of recognition also through materialising practices such as building churches that render migrants and long-standing settlers visible to each other. Tweed (1997) posits that:

$[C]$ onstructing place religiously involves engaging in contests with others within the natural terrain and at social sites.... With and against others in the community ... religious men and women are continually in the process of mapping a symbolic landscape and constructing a symbolic dwelling in which they might have their space and find their place. (p. 93)

The impact of such emplacement by RCCG parishes in Diaspora and elsewhere depicts the importance of religious mapping that is quite obvious in spiritual geography and identity formation in Diaspora. The acquisition of buildings leading to sacralisation of space by RCCG parishes represents a space of achievement in Diaspora as well as Nigeria, in terms of self-sufficiency and embeddedness. Moreover, Christopher (2007) was succinct in his assessment of the impact of placemaking on religious organisations particularly:

Space and memory are twin anchors of any discussion of Diasporas, as diasporic sentiments of affinity for a distant place require reminiscences and their intentional evocation - the recognition of a present absence of a place that must be recalled, if not in physical then in symbolic forms. Diasporic religions are in this sense memory performances. (p. 11)

This is depicted with the creation of spatial memories by African Pentecostal Churches such as RCCG network of parishes through the transposition of landscapes. The ambivalent position of RCCG community of sentiments in Diaspora and continued commitment to RCCG in Nigeria necessitates the use of the social world theoretical framework to understand the ethos and motivations of the RCCG missionary enterprise and trans-border expansion of Redemption Camp.

\section{Social world framework}

Social world is pivotal to the symbolic interactionist perspective from the sociological point of view that considers society as complex relational communication, linking people progressively. This is quite pivotal in a religious organisation such as the RCCG, as members and the leadership potentially create their realities and attitudes as a result of dynamic interactions through shared belief systems, rituals and religious idiosyncrasies in a common social context that is the religious space. This further reinforces Becker's (1986) perspective that provides an interpretative framework of group of actors of diverse interests in a collective action or people 'doing things together' with shared values that in the case of this research are the religious ethos, routinisation and religious creativity in the ever competitive religious space in Nigeria. Social worlds thrive on shared outlooks that constitute the bedrock for shared accomplishment, whilst personal and corporate identities are constituted through assurances and involvement in social worlds and arenas (Shibutani 1955; Strauss 1978). Becker (1982) defined social worlds as groups with shared commitments to certain activities, sharing resources of many kinds to achieve their goals and building shared ideologies on their social, economic, cultural or religious subscriptions. Social worlds are spaces of discourse, major apparatuses through which people organise social life. The social worlds framework depends on Mead's (1964) significant notions of perspective and commitment - which entails all actors (members of RCCG), including social worlds, as corporate actors, having their own standpoints, places of work and obligations to action vis-à-vis the utilitarian situation. The implication of this is reflected in the encompassing vision and mission statements of the RCCG which provides an over aching guide to the leadership of the church which has impacted the entire organisation as a result of their missionary ethos across borders. The shared commitments of RCCG stakeholders 
formed the basis of their modus operandi, whilst each stakeholder in hierarchy of the denomination acts in consonance of RCCG vision and mission statements to form a collective identity through obligations to and involvement in social worlds and arenas in Nigeria and North America. Consequentially, the RCCG appropriates the spiritual capital of its adherents in relation to its missionary ethos as through shared commitments to the expansion of the denomination's ritual, liturgy and inherent appropriation of social space in the creation of Redemption Camp across borders. Spiritual capital thus refers to 'the values, ethics and vision which faith communities to the civil society at local [Nigeria] and global level [North America]...' (Baker \& Skinner 2006:12). This study demonstrates that collective actors within RCCG have their contextual peculiarities, defined geographical space and commitments to action reflecting their commitment to the expansion of Redemption Camps across borders.

\section{History of the Redemption Camp, Mowe, Nigeria}

The historiographies of RCCG in Nigeria and Diaspora have been captured by various scholars in Nigeria and Diaspora (Adeboye 2007:24-58, 2012:147; Adedibu 2018a:169-187, 2018b:1-16; Ukah 2008). In view of the fact that historicisation of RCCG is not the purview of this study, nevertheless, the history of Redemption Camp, Mowe is intricately linked to the growth of RCCG membership under the incumbent General Overseer of RCCG, Pastor E.A. Adeboye who was consecrated on the 21 January 1981 after the demise of the founder late Rev Josiah Akindayomi, who died on the 2 November 1980, aged 71 years. The seedbed of what is today referred to as Redemption Camp on km 46 Lagos-Ibadan Expressway evolved out of the rapid expansion of RCCG under the leadership of Pastor E.A. Adeboye. In 1982, the attendance at the annual convention of RCCG held at the headquarters of the denomination at Ebute-Meta, Lagos, Nigeria was unprecedented as such; there was the need to find an alternative space that could accommodate the congregants during the annual convention.

Tracing the history of Redemption Camp, Foluke Adeboye (in Bankole 1999:69) stated that during one of the several journeys of the Adeboyes from Ilorin to Lagos, Nigeria, where Pastor E.A. Adeboye was a university don, intuitively, Foluke Adeboye informed her husband that the land at Maforija, Epe, Lagos State in Nigeria was not where God wants the RCCG campground to be situated. In fact, the willingness of one Mrs Dake to sell the National Youth Camp (now owned by Foursquare Gospel Church) to the church was unrealistic as RCCG was unable to meet the asking price (Foluke Adeboye in Bankole 1999:69). Recalling the horticultural beauty of the National Youth Camp at Ajebo, Pastor E. A. Adeboye said: 'It was a very beautiful camp, the owners were Americans, the landscaping was super'. Reminiscing about how the site of the Redemption Camp was acquired, Foluke Adeboye (in Bankole 1999) said:
The Lord whispered to me on that day that our camp would be on an Express road. I was a little bit confused. I did not know about this Lagos/Ibadan Expressway at that time. It was just under construction. We were still making use of the Old Ikorodu Road. I told my husband what the Lord has told me. (p. 69)

Eventually, RCCG acquired 4.25 ha of land for a sum of N6000.00 (Lemoshe in Bankole 1999:78-79). Pastor E. Adeboye gave the survey plan of 4.25 ha of land to Engineer Lemoshe to arrange a visit with his secretary, late Pastor Julius Olufemi Akindele (retired assistant general overseer, Missions) to the site. Construction work at the campsite commenced in February 1983 (Adeboye in Bankole 1999:70). Reflecting on the acquisition of the land for the Redemption Camp, Pastor E.A. Adeboye noted that 'the Lord has given it (the total expanse of land) to us because we [RCCG] refused to borrow' (Ojo 1997:9).

In order to raise funds for the acquisition of the campground, Pastor E. A. Adeboye requested for 'ninety-eight (98) people to donate N1000.00 each to join him and his wife' and he promised to give each donor plots of land to build their individual houses (Lemoshe in Bankole 1999:78). Construction work at the Redemption Camp commenced in February 1983 after Pastor E.A. Adeboye shared the vision with many members of the church who came along with him and his wife to the site. Pastor E.A. Adeboye and his wife, Foluke Adeboye, were engaged in manual labour on the campsite to reduce the overhead cost as well as demonstration of exemplary leadership.

Construction at the campsite was executed voluntarily by members and leadership of the Church, including Pastor E.A. Adeboye and his wife, as first auditorium of $150 \mathrm{ft} \times 300$ $\mathrm{ft}$ was built. In 1985, it was expanded to $200 \mathrm{~m} \times 300 \mathrm{~m}$ to accommodate the expanding congregation. The acquisition of the campground and the completion of the Adeboye's unfurnished three-bedroom apartment led to the sacralisation of space hitherto considered as jungle that used to be the habitat of poisonous snakes, wild animals, ancestral worship and veneration by traditional worshippers (Foluke Adeboyein Bankole 1999:70) and dens of armed robbers.

A further 10 ha of land was procured for N10 000, with another 10 ha for N9000. Adeboye claimed that the Lord has given it (the total expanse of land) to us because we (RCCG) refused to borrow' (Ojo 1997:9). A second auditorium further inside the campground was completed in 1995 measuring $395 \mathrm{~m} \times 500 \mathrm{~m}$. Further expansion of the second auditorium by seven columns of $25 \mathrm{~m} \times 500 \mathrm{~m}$ took place in 2001 to accommodate the increasing attendance at various programmes of the Church as observed by Olubiyi (2015:50). What was intended originally to be a quiet prayer camp for supplication and spiritual renewal was now a cynosure of all eyes along the Lagos-Ibadan Expressway and the largest Christian city in Africa (Ojo 1997:50).

In over three decades of existence and rapid development, RCCG has acquired several hectares of land. The congress 
arena (which was the third auditorium) was built to accommodate the ever-increasing congregants for the December event of RCCG known as the Holy Ghost Congress. This is an annual Pentecostal affair of praise and worship, prayers, preaching and charismatic impartation which started in 1998 as a one-night affair at Lekki Peninsula, Lagos, tagged as 'Lekki 98'. It was originally called 'Holy Ghost Festival', and during the convention of the church in August 2001, Adeboye announced that there was a change of name to reflect the true nature of the celebration. Hence, the programme was renamed Holy Ghost Congress. The change of name was to ensure its distinctiveness from the connotation of festival from the African cosmology. It was noted that (RCCG 2010-2017):

[A]n average of 500,000 people attended the Holy Ghost Congress. By 2016, this population increased to 1.1 million and by 2036 it is expected that minimum of 7.5 million will come for the Holy Ghost Congress. (p. 33)

The congress area is made up of a huge industrial building made up of steel poles and wide gable roofs. The roof and the poles have an overall dimension of half a kilometer $(0.5 \mathrm{~km} \times 1 \mathrm{~km})$.

Pastor E. A. Adeboye announced plans to build a new $9 \mathrm{~km}^{2}$ auditorium measuring approximately $3 \mathrm{~km} \times 3 \mathrm{~km}$ during the 2013 August Convention of the denomination in Nigeria which is sited on 90 ha of land in Agunfoye village, off Rev Josiah Akindayomi way, area of the Redemption Camp. The new auditorium was estimated to cost approximately N35 billion (or US\$112 million), whilst the congress arena's cost, popularly called Old Arena, which is utilised for other events, including the first three days of Holy Ghost Congress, annual Ministers Conference and other events of the denomination, was estimated to be about US\$60 million according to Ukah (2018:17). The $3 \mathrm{~km} \times 3 \mathrm{~km}$ auditorium construction work commenced almost immediately through donations from members and friends of the church. Olubiyi (2015:37) writing in the official magazine of RCCG - Redemption Light described the Redemption Camp as 'A City Set on a Hill' with the new auditorium visible on a raised hill even from a distance of $2 \mathrm{~km}$, and perhaps is the largest auditorium in the world. Owing to the enormity of technicalities required for constructing the auditorium through a consortium of Chinese civil construction engineers, the technical expertise of those in academy from the University of Lagos and RCCG's experienced and qualified engineers was coordinated by RCCG's projects and construction division.

The Redemption Camp area in 2016 was estimated to be about 1687 ha with $10 \%$ made up of water bodies (RCCG 2010-2017:1, 32) with over 2500 physical structures such as administrative buildings, orphanage and educational structures (Ukah 2018:3). The land use analysis of Redemption Camp indicates that it comprises the following: 229.7 ha $(13 \%)$ as residential; commercial 10.8 ha $(0.6 \%)$, institutional 143.9 ha $(8.5 \%)$; industrial 3.3 ha $(0.2 \%)$; conservation strip 434.2 ha $(25.8 \%)$, open space 712.4 ha $(42.2 \%)$, recreation 11 ha
(0.7\%), and circulation and car parks 141.4 ha (8.4\%) (Redemption Camp Master Plan 2017:33). Redemption Camp has a population of over 12000 residents (Redemption Camp Master Plan 2017:1). Interestingly, RCCG has succeeded in transposing Redemption Camps to some urban cities in Nigeria such as Portharcourt, Abuja and Jos, whilst in Diaspora, RCCG has campgrounds in South Africa, Cameroon and United States. The next section examines the social world of Redemption Camp through the lens of religious creativity, innovations, routinisation and creativity.

\section{Social world of Redemption Camp through the lens of religious innovations, routinisation and creativity}

Religious creativity and innovations are responses to dynamic changes within the local contexts as well as the forces of globalisation that facilitate fluidity of social and cultural trends across the globe. Redemption Camp, Mowe is a social construct. Members of RCCG and other religious pilgrims who visit the campground assume the holiness ascribed to the site on the attribution of meaning. The construct is a by-product of meaning not from the inherent features of the campground but the attribution of meaning created and experienced through the religious rites and rituals enacted at the sacred site which is not just cognitive-symbolic; people have to do something with their construction of the perceived sacredness of Redemption Camp. This invariably deals with the affirmation of the ritualisation, ceremonies, festivals and exegetical reflection through the sermons of Pastor E.A. Adeboye and other Pentecostal preachers together with charismatic and prophetic activities that are enacted at the sacred space. There is no doubt that Redemption Camp in its founding days was never planned on a drawing board, often not intended to be what it has grown to be and surely was not designed. A major feature of the Redemption Camp as noted by Ukah (2018) is:

[T] he symbolic valourisation, which it has undergone as a place that God had earmarked for the church from the foundation of the earth. Consequently, God's presence is believed to be felt in a special way at this site. The Camp represents an emotionally charged environment for members of RCCG and other 'religious shoppers'. (p. 3)

Durkheim (1995) has captured the impact of congregating in a religiously charged environment as follows:

The very act of congregating is an exceptionally powerful stimulant. Once the individuals are gathered together, a sort of electricity is generated from their closeness and quickly launches them to an extraordinary height of exaltation. Every emotion expressed resonates without interference in consciousness that is wide open to external impression, each one echoing the others. (p. 218)

Durkheim's assertion resonates in the festival-like atmosphere during Holy Ghost Services and other RCCG programmes held at the congress arena as the crowd responds to music with dancing, jumping and blowing of whistle. This type of 
enthusiasm seems infectious amongst the attendees. It is a common sight during the worship and sermon that the laity is actively involved in the liturgy, worship and preaching through call and response.

Redemption Camp, Mowe in the mind of the founding father was aimed to be a place of solitude and spiritual renewal to accommodate the growing membership of the denomination after the 1982 Convention. However, the creativity and ingenuity of Pastor E.A. Adeboye through various programmes aimed at meeting the existential challenges of the attendees. The monthly Holy Ghost Service usually held on the first Friday of the month has been branded not being thematic but also targeted for groups. It has been observed that at times the focus of the monthly Holy Ghost Service is targeted at children, those who are seeking the fruits of the womb (barren women), students and professionals. This seemingly inclusive creativity broadens the general acceptance of RCCG programmes' re-engineering dynamics.

Likewise, the spheres of influence of the members of the laity within the leadership of RCCG are adequately explored to enhance the missionary ethos of the denomination. One of the main players who has accentuated the fortunes of the marketing strategy of RCCG's Holy Ghost Congress is Elder Felix Ohiweri, former managing director/chief executive of Nigerian Breweries Plc. and several other companies and the chairperson of the Holy Ghost Congress public relations committee of RCCG. The planning of the events begins several months ahead with the erection of outdoor billboards in most urban cities of Nigeria and in sub-regions: Ghana, Benin Republic and Cameroon. National dailies and news magazines are inundated with sponsored adverts placed by companies and individuals, church groups and other interest groups urging people to attend RCCG programmes, particularly the Annual Convention and Holy Ghost Congress held in August and December respectively.

The dynamism and re-engineering of the vision of Adeboye for RCCG lead to transforming a day event in 1998 to three days and now a week event. From the onset of the Holy Ghost Congress, Adeboye was the only guest speaker, but since 2002 guest ministers and preachers from various parts of the world have preached at the event held between 20th and 22nd of December. This development seems to be a reflection of the broadening of global image of the denomination as a global missionary player. Guest speakers such as late Myles Munroe, T.D. Jakes, John Hagee, Bamidele Sullivan, Bishop David Oyedepo, Joe Olaiya, Mensa Otabil and most of the prominent Pentecostal/charismatic leaders in Africa have registered their presence at the Holy Ghost Congress.

This invariably has repositioned the RCCG within the global Pentecostal kaleidoscope from an indigenous Pentecostal denomination that is independently funded to a major missionary-sending organisation across the Atlantic. The global missionary aspiration of RCCG is quite evident.
A typical example is the acquisition of Outside Broadcasting Van in 2002 to enable members of the church in Diaspora to watch the programme through Maranatha Christian Broadcasting Station, Dallas. Since 2002, RCCG has consistently improved on the use of media technology for recruitment of their clientele as well as sustenance of ritual cosmos of the denomination because of the compression of time and space. The impact of such a drive is that it has enabled the fluidity of religious subscriptions from Nigeria to other parts of the world.

In the midst of obvious financial crisis and poverty that is a by-product of the moral and financial ineptitude of Nigerian leaders, Adeboye initiated the Divine Encounter programme in February 2001 in response and concern 'over the state of poverty amongst God's children' (Olubiyi 2001:5). The Divine Encounter programme takes place every first Monday of the month. It lasts for one hour, beginning at 08:00. It takes place at the congress arena (main auditorium) of the church at the Redemption Camp. It comprises worship and praise (songs), a sermon, prayers, offering and final blessing. This orientation is consistent with the aspirational messages and financial teachings of Pentecostals across the globe. This is one of the several strands of health and wealth ideals common amongst African Pentecostalism. Nevertheless, Adeboye's focus at the inception of the Divine Encounter was to raise millionaires within his denomination to be God's treasurer; he stated that 'within the next two years when they begin to talk about rich people in the world, many of them will come from RCCG' (Olubiyi 2001:5). Adeboye emerged over the years as a charismatic leader with exceptional religious creativity by offering various rituals as evidenced by multiplicities of programmes that are placed within the grasp of RCCG faithful. This inevitably has led to the emergence of a community of faithful in Nigeria and Diaspora as many seek healings, miracles, anointing, exorcism and deliverance through the routinisation of charisma and rituals of Adeboye.

From the sociological perspective, the emerging socioreligious consumers or adherents of the movement are consistently exposed to various postmodern marketing and communication strategies, including the use of leader's images in production and distribution of religious resources and iconographies, and transmitting transnational bonds with ancillary organisations between institutions established by RCCG. The use of technologies and media avenues has succeeded in blurring the distance between time and space as the media unit of the denomination ensures that liturgical and ritual notions are broadcast live on social media platforms as well as through the satellite broadcasting rights of its television stations. This inevitably has succeeded in the redefinition of religious consumerism as it is no longer territorised and many adherents watch and listen to these programmes and rituals far away from their places of worship, perhaps even at work because of difference in time zone from the place of enactment of such rituals. Thus, most religious organisations not just RCCG that operate such an enterprise have situated their transnational communities to a 
free consumer orientation, as the religious rites and rituals are made available to the multitude of individuals with so much creativity and positive appropriation of media technologies.

Nevertheless, the above model of communication within the religious enterprise, particularly the charismatic movement has been critiqued by scholars such as Enzo (cited in Michel, Possamai \& Turner 2017) as he noted that the:

$[R]$ eligious dimension was not very apparent in their analyses (Le Bon [1895]; Ortegay [1929]; Riseman [1929]; Mose [1950]) as most [of] the authors considered the sacralisation of political power, as occurred under Nazism in German or the deification of Communist collectivism (discussed by Ortegay 1929). (p. 92)

Moreover, Enzo (in Michel et al. 2017:93) provides insight into the underlining sociological dimensions of religious consumerism and sustenance as observed by Canetti (1978) in his classic publication entitled Crowds and Power:

All ceremonies and rules pertaining to such institutions are basically intent on capturing the crowd; they prefer a churchfull secure to the whole world insecure. The regularity of church going and the precise and familiar repetition of certain rites safeguard for crowd something like a domesticated experience of itself. These performances and their recurrence at fixed times supplant needs for something harsher and more violent. (p. 21)

Canetti (1978), as cited in Enzo (Michel et al. 2017:93) above, to a large extent is partially relevant to the emerging sociological profiling of Charismatic enterprise and entrepreneurship prevalent in contemporary Christianity. Consequently, the prevailing postmodern context to a large extent has redefined the impact of religious enterprise such as RCCG; particularly the programmes and rituals led by its General Overseer, Pastor E.A. Adeboye, are no longer territorialised as millions of the community of faithful watch live streaming of these programmes on satellite TV, internet streaming and live radio broadcast across the globe. However, the regularity of RCCG programmes, such as the Holy Ghost Festival, Annual Convention, Holy Ghost Congress and Monthly Holy Ghost Services on the first Friday of every month, has enabled the denomination to recruit and sustain its clientele base as well as foster its missionary drive across borders. The regularity of the programme though predictable, rituals exercised by Adeboye in any of the programmes apart from his sermon are known to the public when he is in the sacred space. The preponderance of suspense by the charismatic leader like Adeboye and his colleagues in the Pentecostal fold is that it gives their adherents the much required elixir to be hopeful that the next event or programme might be their day of healing, deliverance, exorcism or miracles. Indeed, Adeboye has demonstrated that Christianity can both be routinised and charismatic. In Adeboye's orientation, it is a raging geyser of creativity breaking down of accepted norms of people on the Christian faith but proffering Christian solutions through ritualisation and prophetic activities at Redemption Camps.
The propensity for more religious tourism to the sacred space such as the Redemption Camp is a product of claims of meeting existential challenges of people. Moreover, rituality of the leader is preserved as he is presumably understood to be led by the Holy Spirit by their adherents for ritual enactment and the performance of miracles, healings and deliverance. Interestingly, the ability of a denomination such as RCCG to facilitate religious tourism is the continuity of charisma of Adeboye by the creation of Redemption Camps outside Nigeria. Prior to the acquisition of Redemption Camp in Flyod, Texas, the denomination could not hold sway beyond the duration of evangelistic outreaches in any public space utilised for any of its evangelistic programmes in the United States, United Kingdom or in most parts of the Western world and Asia because of cost implications. Meanwhile, with the acquisition of RCCGNA campground in Floyd, Texas, United States, the process of routinisation and charismatic engagement of Adeboye has received impetus for continuity, as adherents at such a space are infused with passion, more opportunities to experience signs and wonders and charisma of the leader as if he (Adeboye) is ministering at the Redemption Camp, Mowe, Nigeria.

The emerging currents within the Nigerian Church scene, particularly in RCCG historiography, is that the political class, as it were, has been observed to attend major evangelistic programmes of the denomination in Nigeria and Diaspora. This development has been aptly documented as the emergence of theocratic class in Pentecostal Republic authored by Ebenezer Obadare (2018). For instance, in the United Kingdom, the former British prime minister, David Cameron, visited the Festival of Life organised by RCCG UK, an event held at Excel London, Royal Victoria Dock, London E16 1XL from 20:00 on Friday, 17 April 2015 till the early hours of Saturday, 18 April 2015. The Festival of Life is the largest evangelistic meeting of Christians in the United Kingdom with over 40000 worshippers in attendance. Cameron's (2015) cameo appearance on the eve of the UK parliamentary elections demonstrates the nature of political class; as they are willing to trade places to enable them achieve electoral success. Both Dr Jonathan Goodluck and Cameron visited RCCG events in Nigeria and London, respectively, were given opportunity to address attendees (Obadare 2006).

Cameron (2015) was at its best as he seized the moment to live up to the rhetoric of giving ephemeral hope to the mostly migrant population in attendance. Unlike the posture of kneeling down associated with humility from the biblical worldview, Cameroon stood whilst prayers were led by Pastor E.A. Adeboye. On the other hand, Dr Jonathan Goodluck, kneeling down meekly before Pastor Adeboye, presented an image of a meek, innocent, harmless and humble servant who would serve Nigerians faithfully, and talk and walk the faith free of corruption, but this seems like a façade. Interestingly, both politicians (Goodluck and Cameron) visited the evangelistic events of RCCG during election periods. Thus, it might be inferred that the political class is ingenious and would do anything within their capabilities to seek electoral victory, including seeking 
endorsement from the ecclesiastical order. Although E.A. Adeboye claims to be apolitical over the years, nevertheless the political class is eager to seek validation from Adeboye in view of his credibility and sphere of influence over the years.

Cameron (2015) played on the rhetoric of familiar socialeconomic frameworks of Africans in Diaspora. He delivered a well-crafted speech along aspirational tendencies associated with Pentecostal adherents and a message of hope of a better life and society to mostly African migrants who might be in margins of the British society. Ironically, Cameron's assertion was irreconcilable, with some of the policies of his administration criticised by various Christian leaders. One of the critics of Cameron's policies was Lord Carey, the former Archbishop of Canterbury. He stated that there is an "aggressive secularist and relativist approach" behind the Government plans to legalise gay marriages and . . . the Prime Minister has "done more than any other recent political leader" to "feed"' (The Huffington Post UK, 2013).

Realising the aspirational nature of Pentecostal teachings hinged on hope through the assistance of transcendentalism, Cameron became a 'prophet' as he proclaimed that an African would one day be the British prime minister. Such assertion is an intentionally couched statement of inclusivity, yet subtle but well-crafted to create connectedness with his audience as many of his listeners, who mostly might be experiencing social, economic or relational discontinuities, a by-product of being either first- or second-generation migrants. Typical British mannerism, Cameron, by appealing to their emotions and sentiments, reminded the attendees of recent developments connected with the kidnapping of 276 schoolgirls by Boko Haram in Nigeria during the preceding week of the Festival of Life event. Interestingly, Cameron's policies were eagerly driving Christians to the margins as they were persecuted; often sought out and framed by homosexual activists because of Cameron's policy on homosexuality and discrimination laws.

After Cameron's couched speech (2015) laden with concise phrases that resonate within the daily experiences of many of the attendees who were mostly migrants of African descent, AguIrukwu, the special assistant to the general overseer, United Kingdom, invited Pastor E.A. Adeboye to pray for David Cameron.

It is imperative to note that the transnational influence of Adeboye and his denomination attract public officers as either a by-product of their inquisitiveness to meet their existential challenges through the ministry of the man of God or a product of seeking an avenue to enhance their political aspirations. I thus aver that despite the visits of politicians to Redemption Camp or RCCG annual conventions, the men of God should not abdicate their prophetic role of speaking the truth to power structures in their communities. Church leaders and their members cannot make moral claims about caring for the souls of people, but then pass and ignore, be indifferent and insular or have unconcerned posture about policies that destroy their bodies and communities.

\section{Politics of place-making of Redemption Camp across borders}

The appropriation of public spaces for religious practices or the sacralisation of spaces in general has been observed to allow migrants momentarily to express an embodied transgression. These sacralised spaces are not only religious amphitheatres but also spaces of hope for the hopeless, freedom and empowerment, no matter how ephemeral it might be to religious adherents. Previous scholarship has examined the role of religion on migrants which has generated a great deal of interests from public policy formulators, town planners and even ecclesiastical orders of various religions, including the Christian traditions, particularly Pentecostalism in Diaspora (Adedibu 2015:233). There seems to be resurgence of focus of researchers on the importance of interaction between space and religiosity, particularly amongst African Pentecostal churches across the Atlantic (Adedibu 2015:212-233; Adogame 2013a:173-194). This highlights saliency of politics of place-making, especially in Africa and Diaspora.

Kong's (1990, 2001) magisterial contributions on the developing notions of spaces of religion are reflected in the concept of new geographies of religion in the 1980s and 1990s. However, there exist potential conflicts with religioussecular urban spaces, and one such way to contribute to this discourse is by examining the transposition of Redemption Camp, Mowe, Nigeria to Flyod, Texas, United States to illustrate the process of emplacement of minority religious movements, such as RCCG, in a new context. This thus entails the legitimate claims of religious movement such as the RCCG to appropriate urban space and the right to use urban spaces to express a sense of belonging in host community as well as adding their presence to religious mosaic in a community. This increasingly is becoming a challenge to public policy formulators and town planners because of local politics of space contestation, particularly in Europe and North America. In view of the permeability of physical border as a result of religious fluidity through the forces of migration, globalisation and technological advancement since the early 1990s, religious ideals and ritual practices are de-territorialised. The obvious import of such a development has led to a good deal of emplacement and politics of space contestation as religious orders from various parts of the globe attempt to assert their presence in host communities which at times is contested by local activists and indigenes who might be averse to the use of their community space for religious emplacement. It is quite evident amongst RCCG parishes that their various rituals and distinctive socio-religious practices that have fostered transnational connections emanating from Nigeria in diverse contexts have provided continuity to their ideals across various cultural frontiers in Africa and Diaspora.

Interestingly, emplacement through acquisition of land or landed properties in Diaspora, particularly in the United States and United Kingdom, is constituted through cooperation and 
conflict that often have major impact of those from the margins in a dominant culture such as ethnic minority religious groups like RCCG parishes. This disposition is predicated on the fact that place identity which ranges from local to national territories which are interwoven, is centrally about the combination of people and institutions. These people and institutions agree upon or recognise themselves as part of a shared community as they are stakeholders to contest any form of intrusion that might contradict the identity of communal or social space (Anderson 1991). These networked communities engage in struggles over (place) definitions at a variety of scales. Bourdieu (2005) notes:

Struggles over ... regional identity ... are a particular case of different struggles over classifications, struggles over the monopoly of the power to make people see and believe, to get them to know and recognize, to impose the legitimate definition of the divisions of the social world. (p. 221)

Bourdieu's assertion raises wider issues with respect to power dichotomy that is evident amongst people group or minority religious groups such as RCCG that are on the margins amongst a dominant group in terms of resources, power and influence. In the light of the missionary orientation of RCCG in urban cities in Nigeria and Diaspora, resacralisation of space is a form of embeddedness and belonging through the acquisition of community, commercial and public spaces of their emplacement in their communities. Cultural activism and politics of place-making bring together diverse set of groups and individuals because of vested interests which range from preservation of community space, aesthetic and political or religious reservations.

The forces of globalisation and technological advancement have contributed to the emergence of a religious community of sentiments far away from the original home context of many religious movements which have of late come under the scrutiny of scholars largely referred to as religious transnationalism (Huwelmeir \& Krause 2011:1-12). Nevertheless, the interconnectedness of religion and transnational networks is not unidirectional but multifaceted as it also positively impacts the religious movements and their ritual practices in transposing their idiosyncrasies across borders. Thus, most religious movements are de-territorialised as a result of the forces of globalisation and are 'to be conceived no more as geopolitical territorial spaces but rather interrelated communicative spaces within a single world' (Cassanova 2012:191-221). It thus becomes pertinent to note that transnationalism has led to lots of reconfiguration, hybridity and religious creativity. The transnational RCCG activities provide a vista of opportunities to engage (Levitt 2001):

... [T] he alternative places of belonging that the religious ideas and symbols make possible and about the ways in which these sacred spaces in which these sacred landscapes interact with the boundaries of political and civil life.... (p. 5)

Consequently, the creation of sacred spaces by religious actors or movements within Africa and Diaspora has been enhanced by socio-economic and political challenges in
Africa as well as educational aspirations of many Africans who are dissatisfied with western form of religious practice and formalism in the new context. Huwelmeir and Krause (in Casordas 2007:261) opine that it is also the ability to create transnational continuity and belonging between different cultures and social contexts'. These transnational religious networks are administered like transnational corporate organisations characterised with unique ecclesiastical structure with well-horned social and economic agenda for their adherents (Mata 2013:1-37). RCCG is an example of one of the transnational African Pentecostal Churches because of its presence across the Atlantic (Adedibu 2012:72; Adogame 2013b:74-76) that is committed to embedding its presence in its host geo-space as a form of acculturation, sense of moving marginality to centre as they acquire space to enable them create and experience their religious brand and rituality. This position is evident in transposition of Redemption Camp in Floyd, Texas, examined in the next section of this article.

\section{Redemption Camp in Floyd, Texas}

The American religioscape was awakened to the reality of the changing Christian landscape as one of the several African Pentecostal denominations made acquisitions in the United States. RCCGNA acquired 800 ha of land in Floyd County, near Dallas, Texas to serve as a hub of its missionary enterprise in North America, dubbed Christian Disneyland. Indeed the whole concept of Disneyland in the American leisure industry was not a new development, but the import of the development was that it was a major shift in the American religioscape. An indigenous African Pentecostal church intended to combine the breathtaking infrastructural development in part of Texas known as redneck of America, a term that describes an entrenched culture of racial bias. This all was done despite the fact that rural Texas is one of the strongholds of the Ku Klux Klan movement, a white supremacist organisation that was known to torture and kill blacks in the early 1960s and 1970s. The process of sacralisation and development in Floyd inevitably generated a good deal of curiosity amongst the locals as well as politics of placemaking so that the RCCGNA leadership had to navigate in the new community. On 17 July 2005, the City of Dallas woke up to the realisation that their neighbourhood was about to witness unprecedented change because of the genesis of initiation of sacralisation of acquired property for the use of one of the seemingly fastest growing denomination of Africa.

In view of the growth and acquisition of properties by the RCCG across the globe, including the transformation of a jungle into a city, the denomination was actively involved in emplacement and space contestation across borders to reposition itself as a major missionary player in the United States. The RCCGNA acquired about 800 ha of land in Floyd (Hunt Count), near Dallas, Texas. The acquired land was modelled similar to the Redemption Camp, Mowe, Nigeria (Akinkoye in Adogame 2014:5). The obvious implications of the modelling of Redemption Camp, Floyd, Texas similar to 
the international headquarters in Nigeria was partly for the emplacement of RCCG as a major religious player in the United States whilst simultaneously providing ample space for the evangelisation agenda of RCCG in North America, as the Redemption Camp, Floyd, Texas would serve as a hub of the operations of RCCGNA. Adogame (2014:51) noted that the 'value of property, infrastructure, and other endowments in these invented religious spaces is quite enormous and monumental'.

This indeed was an American dream for an indigenous African Pentecostal denomination in the United States that was self-governed, self-funded and self-propagated, which seemingly was impracticable in the British space. This might be a herculean task because of various contextual factors, including local politics of space contestation, space activism and community interest, including planning permission from local borough. The obvious implication of this development within the RCCGNA was impact on social, community and human capital developments within the Hunt County as experienced at the Redemption Camp, Nigeria. Owing to the fact that this was a multimillion dollar project; the RCCG was inevitably branding itself into diverse socio-economic and financial sectors within the Nigerian context as well as the global economic gateway. As part of the veneer of sacralisation taking place at Floyd, Texas, the Redemption Camp was the purposefulness and resolute determination of RCCG leadership in Nigeria and the leadership of RCCGNA to assert denomination within the American geo-space to enhance continuity of the transnational ritualisation and charisma associated with the head of the denomination, Pastor E.A. Adeboye. Laolu Akande on 13 June 2013 issued a press release on behalf of the RCCGNA, inviting general public on 19 June 2013 at 17:00 to the opening and dedication ceremony of the RCCGNA's phase one of its worship auditorium at the Redemption Camp, Greenville, DFW Metroplex. Akande (2013) explained that:

$[P]$ hase one of the project which is also known as the Pavilion Centre, seats about 10,000 people but the Worship Auditorium itself is expected to seat over 100,000 when fully completed. (n.p.)

RCCG General Overseer, Pastor E.A. Adeboye dedicated the Pavilion Center worth $\$ 15.5$ million at the start of the church's 17th North America Annual Convention held at the campground on 19 June 2013. The press release highlighted the plan of the RCCGNA as a multimillion dollar project, comprising housing estates, fish farm, schools and a top-rate university, Pavilion Centre and the administrative hub of RCCGNA. Likewise is the $20000 \mathrm{ft}^{2}$ building that now serves as RCCGNA community centre, which also accommodates RCCGNA Bible College and Seminary and its other community initiatives.

The intended transformation of the acquired land in Floyd, Texas received much of media attention. Adogame (2014) noted that Scot Farwel of the Dallas Morning News had a headline on 17 June 2005 as 'African Church Plans Christian Disneyland'. It was disclosed, inter alia that:
[T]he Redeemed Christian Church of God-Africa's largest and most ambitious evangelical church-plans to build a 10,000 seat sanctuary, two elementary school size lecture centre, a dormitory, several cottages, a lake and a Christian themed water park in Floyd, Texas. (p. 50)

Prior to the successful dedication of the 10000 seater worship centre at the RCCGNA Redemption Camp in June 2005, there were intricate challenges of local politics for space contestation and place-making, most of the time sensationalised by media. The impact of such massive media focus lead to mass mobilisation of local conservation activists, local investors, politicians and indigenous members of the community which might ultimately affect local discourses and the decision to grant or deny approval for the development plan of the site. According to Adogame (2013a:186), the provocative news headlines, such as 'A Texas Town Nervously Awaits a New Neighbour' and 'Racist God's Fret as Redeemed Christian Church of God Takes US by Storm', was nerve-wrecking. The two news articles brought into focus the racial antecedent prevalent within the Floyd, Texas axis of Dallas in the past.

Adogame (2013a:186), citing Romero, stated that the RCCGNA paid over ' 1 million dollars for over 500 acres [202.35 ha] of land in Floyd, an incorporated community of less than 100 people, almost all of them white, a few miles away from Greenville'. Some residents of Flyod corroborated the subtle racial demography indicated by Romero (Adogame 2013a) above. For instance, Romero quoting Tina Causey, a female house cleaner who lived with her husband in Floyd, stated that 'the Nigerians I've seen on TV (the television) are dark, really dark not like the people around here'. Similarly, a view was expressed by Isham, interviewed by Romero, who said that he had 'nothing against black people, but I just don't like the ones who do drugs'. This smacks subtle prejudice of which the neighbourhood was noted for. To underscore the perception of the people of Floyd on race matter has been a sour grape in the United States for a while, but some of the assertions are contestable (Adogame 2013a:186). Omatseye citing Adogame 2013a reported that despite prior racial challenges in Floyd, Texas:

... [T] he RCCG chose neither Dallas nor Houston nor even Austin, which enjoys a variegated racial mix, but Floyd, a rural backstreet. The RCCG says the choice of Floyd was not the province of man, God pointed the way. (p. 186)

In the light of perceived intrusion by RCCGNA, as perceived by some residents of Floyd, Texas, to local ecology, socioeconomic as well as racial change to the demography of the local context, some of these perceptions was treated with genuine concern and empathy by the leadership of RCCGNA by engaging locals as well as public servants within the Texas axis to disabuse their minds with respect to the motive of the denomination within their jurisdiction. Despite the scepticism of some residents of Floyd, it is pertinent to note that Romero's interview also revealed that some of the inhabitants of the Floyd were indifferent to the imminent demographical and racial change of the community, particularly some of those who grew up in the 
city in post-segregation era as well as those who had experienced multicultural ambience in some RCCGNA parishes like Marti Garner who grew up in Hunt County, Floyd. She and her husband, who are ministers with the denomination, were credited with selling part of the newly acquired campsite to RCCGNA (Adogame 2013a:186-187).

The understanding of local politics and leadership engagement are pivotal in the politics of space contestation, despite the uncertain welcome of RCCGNA in Floyd. In 2003, leadership of the denomination must have worked out strategies that were broadly acceptable to the local and political actors within the Texas state to give legitimacy to their continued occupation of campground. The seemingly apolitical disposition of RCCG leaders smacks behind the scene brinkmanship and strategic alignment within the remit of legal statues of land as well as recognition and engagement with power structures in the communities. This subtle, disarming recognition given to public officers, including the Governor of Texas and the Mayor of Dallas, at annual opening ceremonies of RCCGNA might be construed as being the political dimensions of RCCGNA (Adogame 2013a:186). A similar disposition of the church is noted in RCCG Nigeria during the various monthly and annual events of the church. Thus, courtesy visits to public servants are common occurrences with RCCG leadership across the Atlantic, although the charismatic leader, E.A. Adeboye consistently claims to be apolitical. Nevertheless, the altruistic nature of the preceding assertion might not be a reality as some members of RCCG are politicians as well as prominent civil servants and might want to extend their goodwill to the denomination particularly in Nigeria and Africa.

Although statutory requirements exist in the Nigerian context, speculative land sales and family feuds are more of a challenge than activities of secular humanist, stringent planning permission, local politics and fiscal challenges are major constraints for most African Pentecostal churches in the West in their bid for emplacement in their new context. However, the author was informed by unanimous leaders of the church that there were counter claims of land ownership by various communities in Ogun State, Nigeria, leading to multiple payments as well as haggling with statutory agencies on land matters. Redemption Camp demonstrates the role of religious organisations such as RCCG through the process of sacralisation of space, which does generate huge dynamic interface of social, cultural, educational and economic development as well as religious consumerism.

\section{Conclusion}

The transnational positioning of RCCG is evident in the transposition of Redemption Camp from Nigeria to Floyd, Texas as an avenue for the leadership of RCCGNA to connect with their communities and country of origin, especially the ritual peculiarities of RCCG away from the Nigerian context. Thus, the inherent contextual factors of space contestation and place-making in a developing society such as Nigeria are quite different from that in West.
Nevertheless, statutory requirements in terms of planning permission and land acquisition resonate in two contexts. However, there exist various contextual factors such as governmental development plans, planning regulations as well as neighbourhood projections. Activities of community interest groups and financial considerations constitute constraints of emplacement of minority religious groups such as RCCG in Diaspora in comparison to the Nigerian context. Therefore, place-making and space contestation for emplacement of RCCG ideals through the replication of Redemption Camp across borders in the West require astute knowledge of statutory, legal and urban planning requirements, extensive financial implications as well as understanding local politics of community leaders and activists.

\section{Acknowledgements}

I acknowledge the concession of Pastor J.F. Odesola, Assistant General Overseer (administration and personnel), who granted the permission for this research to be conducted in Redeemed Christian Church of God, Redemption Camp, as well as Dr Benson Igboin for his comments on the preliminary writeup.

\section{Competing interests}

The author declares that he has no financial or personal relationships which may have inappropriately influenced him in writing this article.

\section{Author's contributions}

B.A.A. is the sole author of this research article.

\section{Ethical considerations}

This article followed all ethical standards for a research without direct contact with human or animal subjects.

\section{Funding information}

This research received no specific grant from any funding agency in the public, commercial, or not-for-profit sectors.

\section{Data availability statement}

Data sharing is not applicable to this article as no new data were created or analysed in this study.

\section{Disclaimer}

The views and opinions expressed in this article are those of the author and do not necessarily reflect the official policy or position of any affiliated agency of the author.

\section{References}

Adeboye, O., 2007, 'Arrowhead' of Nigerian Pentecostalism: The Redeemed Christian Church of God, 1952-2005', Pneuma 29(1), 24-58 (35). https://doi.org/10.1163/ $157007407 \times 178238$ 
Adeboye, O., 2012, 'A church in a cinema hall?' Pentecostal appropriation of public space in Nigeria', Journal of Religion in Africa 42(2012), 145-171. https://doi. space in Nigeria', Journal of Religior
org/10.1163/15700666-12341227

Adedibu, B., 2012, Coat of many colours: Origin, growth, distinctiveness and contributions of Britain's black majority churches to British Christianity, Wisdom Summit, Gloucester.

Adedibu, B.A., 2015, 'Fromhouse cell to warehouse churches: The reworlding of the British Christian landscape by African Pentecostal churches in London', Ekpom Journal of Religious Studies 10(1 \& 2), 212-233, Ambrose Ali University, Benin.

Adedibu, B.A., 2018a, 'Mission out of Africa: The case of the Redeemed Christian Church of God in the United Kingdom 1988 to date', in D.Goodhews \& A.-P. Cooper (eds.), Desecularisation of the city: London churches since 1980 till the present, pp. 169-186, Routledge, London.

Adedibu, B.A., 2018b, 'Mission out of Africa: The urbanisation of the Redeemed Christian Church of God in the United Kingdom and its missional implications', interkulturelle theologie zeitschrift für missionswissenschaft [Intercultura Theology: Journal of Missiology] 2018(1), pp. 1-16.

Adogame, A., 2013a, 'Toward a Christian Disneyland? Negotiating space and identity in the new African religious diaspora', in A. Kane \& T. Leedy (eds.), African migrations, Indiana University Press, Bloomington, IN.

Adogame, A., 2013b, The African Christian diaspora: New currents and emerging trends, Bloomsbury, London.

Adogame, A., 2014, 'The Redeemed Christian Church of God: African Pentecostalism', in S. Cherry \& H.R. Ebaugh (eds.), Global religious movements across borders, n.p., Ashgate, London.

Anderson, B., 1991, Imagined communities, reflections on the origin and spread of nationalism, Verso Books, London.

Baker, C. \& Skinner H., 2006, Faith in action: The dynamic spiritual and religious capital, William Temple Foundation, London.

Bankole, O., 1999, The trees do clap their hands, El Shalom, Lagos, Nigeria.

Becker, H.S., 1982, Art worlds, University of California Press, Berkeley, CA.

Becker, H.S., 1986, Doing things together, Selected Papers, Northwestern University Press, Evanston, IL.

Bourdieu, P., 2005, Language and Symbolic Power, Polity, Cambridge.

Cameron, D., 2015, The prime minister of United Kingdom @ RCCG Festival of Life, London, April 2015, viewed 06 January 2009, from https://www.youtube.com/ watch?v=uz6P_ruQL9A.

Canetti, E., 1978, Crowds and power, Seabury Press, New York (originally published in German, 1960).

Casordas, T., 2007, 'Modalities of transnational transcedence', Anthropological Theory 7(3), 259-272. https://doi.org/10.1177/1463499607080188

Cassanova, J., 2012, 'Religion, the axial age, and secular modernity in Bellah's theory of religious evolution', in R. Bellah \& H. Joas (eds.), The axial age and its consequences, The Belknap Press of Harvard University, Cambridge, MA.

Christopher, J., 2007, Paul diaspora conversions: Black Caribbean religion and the recovery of Africa, University of California Press, Berkeley, CA.

Durkheim, E., 1995, The elementary forms of religious life, Free Press, New York.

Eade, J., 2011, 'From race to religion: Multiculturalism and contested urban space', in J. Beaumont \& C. Baker (eds.), Postsecular cities: Space, theory and practice, pp. 154-167, Continuum International, London.

Harvey, D., 1993, 'From space to place and back again: Reflections on the condition of Postmodernity', in J. Bird, T. Curtis, G. Putnam\& L. Tickner (eds.), pp. 3-19, Mapping the futures: Local cultures, global change, Routledge, London.

Huwelmeir, G. \& Krause, K., 2011, Travelling spirits: Migrants, markets and mobilities, Routledge Press, New York.

Knott, K., 2005, The location of religion: A spatial analysis, Equinox, London.

Knott, K., 2010, March, 'Religion, space, and place: The spatial turn in research on religion', Religion and Society: Advances in Research 1(1), 29-43. https://doi. org/10.3167/arrs.2010.010103

Kong, L., 1990, 'Geography of religion: Trends and prospects', Progress in Human Geography 14(3), 355-371. https://doi.org/10.1177/030913259001400302
Kong, L., 2001, 'Mapping "New" geographies of religion: Politics and poetics in modernity', Progress in Human Geography 25(2), 211-233. https://doi.org/ modernity, Progress in Human
$10.1191 / 030913201678580485$

Le Bon, G., 1895, Psychologie des foules, Alcan, Paris, France (English version: The psychology of the crowds, Sparkling Books, Southampton, UK, 2012).

Lefebvre, H., 1991, The production of space, Blackwell, Oxford.

Levitt, P., 2001, 'Between God, ethnicity, and country: An approach to the study of transnational religion', Paper presented at Workshop on 'Transnationa migration: Comparative perspectives', 30 June-01 July, 2001, Princeton University, Princeton, viewed 15 January 2019, from http://www.transcomm. ox.ac.uk/working\%20papers/Levitt.pdf.

Massey, D., 1994, Space, place, and gender, University of Minnesota, Minneapolis, MN.

Massey, D., 2005, For space, Sage, Thousand Oaks, CA.

Mata, K. (ed.), 2013, Religion: Help or hinderance to development?, Evangelishche Verlangstalt/The Lutheran World Federation, Lutheran World Federation, Geneva.

Mead, G.H., 1938, The Philosophy of the Act, C.W. Morris, J.M. Brewster, A.M. Dunham \& D.L. Miller, (eds.), University of Chicago Press, Chicago, IL.

Mead, G.H., 1964, Selected writings, A.J. Reck (ed.), University of Chicago Press, Chicago, IL.

Michel, P., Possamai, A. \& Turner, B. (eds.), 2017, Religions, nations and transnationalism in multiple modernities, Palgrave Macmillan, New York.

Obadare, E., 2006, 'Pentecostal Presidency? The Lagos-Ibadan "Theocratic Class" and Muslim "Other"', Review of African Political Economy 33(110), 665-678.

Obadare, E., 2018, Pentecostal republic: Religion and the struggle for state power in Nigeria, Zed Publisher, London.

Ojo, T., 1997, Let somebody shout Halleluyah, Honeycombs Cards and Prints, Lagos, Nigeria.

Olubiyi, O., 2001, 'Divine encounter: A life changing programme', Redemption Light 6(4), 2001.

Olubiyi, O., 2015, 'RCCG: A city on the hills, Lagos', Redemption Light, Lagos, Redeemed Christian Church of God, s.l.

Ortegay, G.J., 1929, La rebellion de lasmasas, El Sol, Madrid.

PR Newswire, 2013, Pastor Adeboye dedicates Redeemed Christian Church of God, North America multi-million dollar pavilion center in Dallas-Fort worth next week, viewed 05 January 2019, from https://www.prnewswire.com/news-releases/pastor-adeboyededicates-redeemed-christian-church-of-god-north-america-multi-million-dollarpavilion-center-in-dallas-fort-worth-next-week-211353701.html.

Redeemed Christian Church of God (RCCG), 2010-2017, Physical Planning Department, Redeemed Christian Church of God, Mowe.

Riseman, D., Denney, R. \& Glazer, N. (eds.), 1950, The lonely crowd: A study of the changing American character, Yale University Press, New Haven, CT.

Shibutani, T., 1955, 'Reference groups as perspectives', American Journal of Sociology 60(6), 522-529. https://doi.org/10.1086/221630

Soja, E., 1989, Postmodern geographies: The reassertion of space in critical socia theory, Verso Press, London.

Soja, E., 1996, Third space: Journeys to Los Angeles and other real-and-imagined places, Basil Blackwell, Oxford.

Strauss, A., 1978, 'A social world's perspective', Studies in Symbolic Interaction 1, 119-128.

The Huffington Post UK, 2013, 'George Carey, former archbishop, criticises Cameron for "feeding fears of Christian persecution"', The Huffington Post UK, 30 March, viewed 06 January 2009, from https://www.huffingtonpost.co.uk/2013/03/30/ viewed 06 January 2009, from https://www.huffingtonpost.co.uk/2013/03/30/

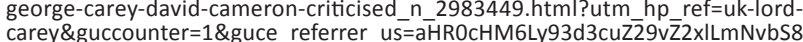
carey\&guccounter $=1 \&$ guce $r$ referrer_us=aHROch
\&guce_referrer_cs $=$ HhNVBOhF5EFplyPh4fgPyA

Ukah, A., 2008, A new paradigm of Pentecostal power: A study of the Redeemed Christian Church of God, Africa World Press, Trenton, NJ.

Ukah, A., 2018, 'Emplacing god: The social worlds of miracle cities - Perspectives from Nigeria and Uganda', Journal of Contemporary African Studies 36(2), 1-18. https://doi.org/10.1080/02589001.2018.149209 